\title{
Artelogie
}

Recherche sur les arts, le patrimoine et la littérature de l'Amérique latine

$4 \mid 2013$

Fêtes et célébrations en Amérique latine

\section{Festas, patrimônio cultural e identidade negra. Rio de Janeiro, 1888 - 2011}

\section{Martha Abreu e Hebe Mattos}

\section{OpenEdition \\ Journals}

Edição electrónica

URL: https://journals.openedition.org/artelogie/6208

DOI: $10.4000 /$ artelogie.6208

ISSN: 2115-6395

Editora

Association ESCAL

Refêrencia eletrónica

Martha Abreu e Hebe Mattos, «Festas, patrimônio cultural e identidade negra. Rio de Janeiro, 1888 2011», Artelogie [Online], 4 | 2013, posto online no dia 02 fevereiro 2013, consultado o 01 dezembro 2021. URL: http://journals.openedition.org/artelogie/6208 ; DOI: https://doi.org/10.4000/artelogie. 6208

Este documento foi criado de forma automática no dia 1 dezembro 2021.

Association ESCAL 


\title{
Festas, patrimônio cultural e identidade negra. Rio de Janeiro, $1888-2011$
}

\author{
Martha Abreu e Hebe Mattos
}

\begin{abstract}
Este texto faz parte de um projeto de pesquisa, desenvolvido em conjunto com Hebe Mattos desde 2005, sobre o ressurgimento de jongos e quilombos no Rio de Janeiro como manifestações

políticas e culturais contemporâneas.
\end{abstract}

Há pelo menos duas décadas, o estudo sobre as festas populares, antigamente domínio de folcloristas e antropólogos, tem crescido na produção historiográfica brasileira. Vistas como locais de encontro, janelas para o estudo de uma dada conjuntura, caminhos de conflito e/ou formação de identidades (étnicas, locais ou nacionais), são inúmeros os significados e interpretações que os historiadores têm atribuído às festas. Com trabalhos escritos a partir de correntes da história cultural francesa ou das que não abrem mão de valorizar as lutas sociais em torno da cultura, as festas definitivamente ganharam um espaço de reflexão entre os historiadores. Por outro lado, questões centrais aos estudos da História hoje, como o agenciamento dos atores sociais, a construção de memórias e patrimônios, a formação de identidades e representações, as aproximações entre política e cultura, passaram a fazer parte dos interesses dos que se dedicam aos estudos sobre as festas, em diferentes períodos e regiões ${ }^{1}$. Dentre os poucos consensos que podemos encontrar na historiografia que colocou as festas no centro de suas atenções, talvez possa ser destacada a certeza de que as festas pertencem à História e ao nosso domínio de investigação. Em decorrência, é possível fazer emergir outra certeza: a de que as festas nunca tiveram um período único de esplendor, em algum local maravilhoso do passado. As festas - e tudo o que elas apresentam e representam - em nenhum tempo alcançaram unanimidade. Mesmo reunindo em torno de si muitos adeptos e festeiros, sempre atraíram críticos, opositores, perseguidores ou nostálgicos de outros tempos. Conflitos, mudanças, negociações e memórias compõem a história das festas - de todas as festas². A partir 
dessas questões, especialmente das relações entre festa e identidade, entre festa, memória e luta política, pretendo trazer ao leitor nesse trabalho uma festa de uma pequena localidade, distante do Rio de Janeiro cerca de 3 horas, o Quilombo São José da Serra, no município de Valença. Apesar de o local ser distante, de difícil acesso e muito isolado, a repercussão recente dos seus tambores, versos e danças tem sido impressionante. A festa se realiza todos os anos no dia 13 de maio ou em data próxima e seus festeiros são descendentes da última geração de africanos e escravizados do velho Vale do Paraíba cafeeiro. Reivindicam hoje o título e os direitos de remanescentes das comunidades dos quilombos, a partir do Artigo 68 dos Atos das Disposições Constitucionais Transitórias da Constituição Brasileira de 1988. Depois de mais de 15 anos de luta, a vitória e o reconhecimento de suas terras parecem estar próximos ${ }^{3}$. Embora tenhamos referências diretas de que as festas de 13 de maio acontecem desde a década de 1990, é possível pensar, a partir de entrevistas realizadas com os mais velhos e informações de folcloristas, que são muito antigas. Devem remontar mesmo a maio de 1888, quando já encontramos o jongo como uma das grandes atrações das comemorações pela Abolição da escravidão. $O$ jongo, também conhecido como caxambu, pode ser definido em termos gerais como uma dança em círculo acompanhada de tambores, palmas e de uma fogueira. No centro da roda, um casal apresenta as principais evoluções e os velhos jongueiros, acompanhados pelo coro dos participantes, colocam versos de improviso. Para Robert Slenes, o jongo do sudeste apresenta diversos sinais de sua estreita relação com práticas culturais Bantus da África central. A região foi a principal área de procedência dos africanos escravizados no sudeste do Brasil e os chamados povos Bantus compartilhavam muitas proximidades lingüísticas e religiosas. Além de palavras em kikongo e kimbundo, a presença das fogueiras e do fogo no jongo remete a elementos simbólicos importantes do culto aos ancestrais. As puítas, os tambores, a dança de casais ao centro da roda, assim como os desafios em versos e pontos colocados sob a liderança dos mais velhos, em linguagem cifrada e metafórica, também foram vistos e descritos por viajantes do século XIX e início do XX, na região do Congo e Angola ${ }^{4}$. Em São José da Serra o jongo é o momento máximo das comemorações em torno do 13 de maio. Um dos versos cantados pelos festeiros sob a forma de ponto de jongo expressa diretamente a importância do marco da Abolição para comunidade e, consequentemente, para suas festas : "Negro no cativeiro. Passou tanto trabalho. Ganhou sua liberdade. No dia 13 de maio"s

\section{Uma festa para não ser esquecida}

2 Apesar de serem pouco lembradas hoje, as festas em comemoração ao dia 13 de maio no próprio ano de 1888 foram intensas e marcantes. Além das autoridades, abolicionistas, parlamentares, jornalistas, associações de classe e irmandades, o povo das ruas, nem sempre de forma muito organizada, teria também comemorado com muita vontade a Abolição da escravidão. Especialmente para a imprensa, abolicionistas e parlamentares, segundo os recentes trabalhos de Renata Moraes e Matheus Serva Pereira, as festas acompanhadas de missas, discursos, poesias e préstitos - foram organizadas para não serem esquecidas ${ }^{6}$. Envolvidas com as disputas entre monarquistas e republicanos, as comemorações oficiais ou populares pela Abolição, em diversas partes do Brasil, percorreram toda a Primeira República e grande parte do século XX. De acordo com Petrônio Domingos, o marco do 13 de maio foi mantido por diversas organizações, clubes, irmandades e jornais negros de São Paulo, ao longo das primeiras décadas do 
século XX, como um dia importante para reflexões e denúncias sobre a situação dos negros. Entre muitos significados, também era uma data para atividades culturais, encontros festivos e muitos "batuques, sambas, jongos e congadas..." não tendo desaparecido, as festas oficiais ou organizadas por lideranças negras acabaram sendo menos lembradas, principalmente após o Estado Novo, quando o feriado em 13 de maio foi até mesmo suspenso. Na década de 1970, o Movimento Negro Unificado (MNU) e o predomínio de certa interpretação marxista da história acabaram contribuindo para sepultar de vez esse marco como motivo para alguma comemoração festiva ${ }^{8}$. As organizações negras investiram em outra data: escolheram o dia 20 de novembro - o dia de Zumbi, símbolo da resistência e da opressão racial - como o dia da Consciência Negra. Os historiadores, por seu lado, passaram a considerar que as leis abolicionistas não eram dignas de comemoração ; tinham mudado muito pouco a vida dos escravizados e seus descendentes. Não havia o que comemorar. 013 de maio e a Princesa Isabel para esses atores sociais estavam condenados ao desprestígio e ao consequente desaparecimento como marcos históricos a serem guardados, ao menos nos grandes centros, na imprensa em geral, nos livros didáticos e em muitos textos acadêmicos. Embora desprestigiadas, as festas em torno da Abolição não foram esquecidas em todos os lugares e os tambores do jongo, ao longo do século XX e início do XXI, não silenciaram nessa data. Para os descendentes de escravos do Vale do Paraíba as atuais festas e as referências ao 13 de maio - muitas vezes em pontos de jongo - passaram a fazer parte do patrimônio cultural, festivo, religioso e musical de suas comunidades, mesmo que tenham adquirido diferentes e conflituosos significados. E desde muito tempo... Já em 1888, localizamos comemorações de libertos com batuques (termo genérico que nomeava as danças negras e na maioria das vezes se aproximava do jongo do sudeste), como na célebre imagem de Ângelo Agostini para a Revista Ilustrada do Rio de Janeiro, em 2 de junho de 1888. Na legenda, publicada abaixo da imagem de libertos numa dança de roda, o autor explicava que os "novos cidadãos", após a Abolição, "entregam-se ao mais delirante batuque !...". Em torno da fogueira, continuava, ardiam os "troncos, bacalhaus e outros instrumentos de tortura". Para o interior da velha província do Rio de Janeiro, o historiador Stanley Stein descreveu o êxodo em massa das fazendas, logo após ao fim do cativeiro, quando muitos libertos dirigiram-se para as "estradas secundárias, parando para perguntar pelos amigos e parentes, acampando perto das tabernas de beira de estrada para dançar, cantar o jongo e conversar". Segundo o autor, "durante três dias e três noites podia-se ouvir os tambores reverberando enquanto libertos regozijavam-se com o caxambu" (um dos tambores do jongo). ${ }^{10} \mathrm{Um}$ ano depois do fim do cativeiro, o verbete sobre o jongo, publicado no dicionário de Macedo Soares em 1889, citava uma notícia do Jornal do Comércio, de 14 de maio daquele ano, sobre libertos dançarem "alegres jongos em regozijo pelo aniversário da abolição"! $!^{11}$ Algum tempo depois do 13 de maio de 1888, mesmo com todos os problemas enfrentados pelos libertos e os evidentes limites à liberdade, as comemorações nessa data com encontros de jongueiros não parecem ter sido interrompidas, muito menos esquecidas. Para as primeiras décadas do século XX, o historiador Jaime de Almeida, em São Luís de Paraitinga, estado de São Paulo, encontrou registros de jongo ao lado de uma importante mobilização política nos meses de maio de 1916 e $1917^{12}$. Vários também são os registros de folcloristas para o velho sudeste escravista em momentos posteriores. O músico Luciano Gallet, por exemplo, registrou um ponto de jongo, na década de 1920, numa fazenda perto do Rio Piraí, estado do Rio de Janeiro, onde uma "rainha", ao que tudo indica a princesa Isabel, havia ordenado parar o trabalho ${ }^{13}$. No interior do estado de São 
Paulo, em áreas próximas ao Vale, estudantes da USP, mobilizados por pesquisadores como Antonio Candido e Lavínia Reynolds na década de 1940, assistiram festas com jongos próximas ao dia 13 de maio. Em 1943, os informantes de Lavínia Reynolds, em Tietê, estado de São Paulo, disseram gostar de batucar no 13 de maio, embora também aproveitassem os dias de festas religiosas para o jongo. Em 1944, o Departamento Estadual de Imprensa e Propaganda do Estado de São Paulo (DEIP) teria registrado um batuque em Vila Santa Maria, cidade de São Paulo, exatamente no dia 13 de maio, quando um informante avisara que o jongo ficava mais animado. Alceu Maynard Araújo, em São Luís do Paraitinga, assistiu a um jongo em 13 de maio de 1947 (seriam os mesmos jongueiros de 1916 e 1917 ?). Por sua vez, Maria de Lourdes Borges Ribeiro, uma das maiores pesquisadoras do jongo, registrou um ponto que fazia referência à data do 13 de maio ser dia de grande alegria. Bem mais tarde, Raul Lody, em 1976, foi informado pelo Sr. Ermes Silva, conhecido jongueiro de Campos no estado do Rio de Janeiro, sobre as três semanas de alegria e festas com tambor, quando a Princesa Isabel acabou com a escravidão ${ }^{14}$. Na década de 1950, o historiador Stanley Stein ainda alcançou significativas lembranças de ex-escravos sobre a Abolição articuladas à prática do jongo em Vassouras, município do estado do Rio limítrofe ao de São José da Serra. No último capítulo de sua obra, "A abolição e suas conseqüências", para além do drama vivido pelos senhores do café, apresentou alguns pontos de jongo cantados por descendentes de africanos. Alguns desses pontos, ou versões muito próximas, ainda podem ser ouvidos no Vale do Paraíba, cantados pela própria comunidade de São José da Serra ou por grupos convidados para sua festa, como os de Pinheiral e Miracema.Entre os pontos de jongo que Stein ouviu e gravou quando fazia a pesquisa sobre a escravidão em Vassouras, muitos estavam diretamente ligados aos acontecimentos do dia 13 de maio $\mathrm{e}$ com a própria princesa Isabel, identificada também como "rainha" : "Eu tava dormindo, ngoma me chamou. Levanta povo, cativeiro já acabou"; "Eu pisei na pedra, pedra balanceou. Mundo 'tava torto' rainha endireitou" ${ }^{15}$ Outros pontos citados pelo autor, além da memória da Abolição, ainda evidenciavam atitudes de ousadia e ironia, típicas da tradição oral dos pontos de jongo, em grande parte marcada pela linguagem cifrada e metafórica. Especialmente um deles criticava os limites da Abolição, e fazia referência à liberdade que não veio completa: "Dona rainha me deu uma cama. Não me deu banco pra me sentar"16 Ainda teríamos outros exemplos para mostrar como, através da música, dos jongos e das festas, o dia 13 de maio foi lembrado e comemorado pelos descendentes dos últimos escravos, em diferentes locais dos estados do Rio de Janeiro e São Paulo ao longo do século XX. Mas entendo que já reunimos suficientes exemplos para convencer o leitor o quanto a memória da Abolição (e indiretamente da escravidão) foi não apenas celebrada, mas também justificou-e justifica até hoje- os encontros que transformaram o jongo e a própria festa em patrimônio cultural dos grupos e comunidades participantes. Sem dúvida, as festas em torno da Abolição, comemoradas nos antigos vales do café com jongos e caxambus, podem ser vistas atualmente como um importante canal de expressão e de comunicação para os descendentes da última geração de africanos e escravos do sudeste. Sem acesso à terra e à política formal, transformaram a prática cultural em local de memória e história ; a festa, em canal de expressão identitária e política. ${ }^{17}$ As festas de maio do Quilombo São José da Serra são um dos melhores exemplos dessa transformação... 


\section{São José da Serra - novos caminhos do jongo}

3 Pelo que conseguimos apurar, os encontros de maio em São José chegaram a durar mais de uma semana. Nos últimos tempos, concentram-se em um fim de semana próximo ao dia 13 de maio e continuam a atrair a população de regiões próximas. Especialmente depois do reconhecimento da comunidade pelo INCRA (Instituto Nacional de Colonização e Reforma Agrária) como remanescente de quilombo, no final dos anos 90, e da atuação de um de seus maiores líderes, Antonio Nascimento Fernandes, o Toninho Canecão, as festas em comemoração ao 13 de maio passaram a sediar "verdadeiros festivais de jongo", atraindo centenas de "pesquisadores, jornalistas e amantes da música negra tradicional" ${ }^{18}$, além de grupos de jongueiros, foliões de reis e calangueiros de outras áreas mais distantes. A comunidade de São José da Serra começou a ganhar visibilidade.Paralelamente, processo que acompanhamos de perto ao longo da primeira década do século XXI, novas disputas pelos significados das festas, protagonizadas pelos festeiros de São José da Serra, demonstram a politização de suas comemorações e a abertura de novos canais de expressão. Primeiramente, observamos o intencional deslocamento do marco de 13 de maio para o dia 1ํ. de maio. Em segundo lugar, a maior valorização das festas de novembro. Sob a liderança de Toninho e a partir de sua participação no movimento negro, começou a ganhar importância a festa da Consciência Negra, celebrada nacionalmente em 20 de novembro. As festas de maio, se em algum local do passado eram vinculadas às comemorações da Abolição de 1888 e ao consequente papel de destaque da Princesa Isabel, passaram a ser fixadas em torno do dia $1^{\text {ô }}$. de maio, em comemoração a São José Operário, santo que nomeia a própria fazenda. Não é pouco lembrar que o dia $1^{\circ}$. De Maio é feriado no Brasil, em função das comemorações do dia do trabalhador. Recentemente, entretanto, a festa retornou ao marco do dia 13 de maio, mas com substanciais modificações em seus significados. Pelo que nos foi informado, o deslocamento para o dia $1^{\circ}$. de maio teria descontentado os mais antigos que tradicionalmente também dedicavam esse dia aos Pretos Velhos, entidade espiritual dos centros de umbanda e candomblé diretamente relacionada aos antepassados escravos mais velhos. A comunidade de São José da Serra também possui um centro religioso de umbanda que é referência espiritual importante das regiões próximas. De fato, as festas hoje na comunidade acontecem de novo em torno do dia 13 de maio - e com força total. Pelo que divulgam oficialmente nos cartazes e convites para a festa, mas também pelo que está presente das falas dos festeiros, o Quilombo de São José da Serra comemora em torno do dia 13 de maio a memória dos Pretos Velhos. Se o deslocamento do que se comemora é marcado pela tentativa de esquecer o papel da princesa Isabel, o passado escravo dos seus avós e bisavós não é esquecido. Pelo contrário, a associação do dia dos Pretos Velhos com o 13 de maio estabelece uma ponte direta com o tempo do cativeiro, com os antepassados escravos e com a data do fim da escravidão. Abre ainda novas possibilidades às festas de maio, que incorporam, através da visibilidade do jongo, as bandeiras de luta dessa comunidade de descendentes de escravos, como o direito à terra, à reparação, à sustentabilidade do grupo através do turismo cultural e à valorização de uma identidade negra e afro-brasileira. As palavras de Toninho Canecão, em entrevista à Hebe Mattos, no LABHOI, em 2003, quando procurava explicar o passado do jongo e seu potencial político, através da união e visibilidade do grupo, podem dar uma boa idéia dos significados da festa e do jongo para a comunidade : 
O jongo da Comunidade São José da Serra é uma das coisas que a gente tem consciência [que] é uma das coisas boas, porque o jongo ele foi criado assim : no tempo da escravidão, então o negro vinha lá de fora da África e quando chegava no Brasil eles faziam tudo pra poder trocar, tirar parentesco, grau de parentesco. Cada um levava para um lugar aí até com língua diferente [...] até dialeto não falava o mesmo [...] para poder complicar a convivência deles nas comuni... nas fazendas. E no jongo, os negros se organizaram através do cântico. Então começaram a cantar... e cantando eles se conheciam, através do canto e daquilo foi surgindo algum namoro, nas lavouras de café. E passaram a um confiar no outro. E assim foi criado o Quilombo também. Porque o jongo ele é um cântico não decifrável. Porque o cara cantava, combinava quem ia fugir, como ia fugir, quando iria fugir, com quem iria fugir. Mas os feitores, que ficavam o dia todo nas lavouras de café não tomavam conhecimento daquilo. Aí foi indo, com o passar do tempo, aí foi criando os quilombos. Veio o dos Palmares, depois vem outros quilombos como hoje é o de São José da Serra [...]. Mas eu vejo também a salvação disso tudo é o jongo. A gente [...] vem aqui no Rio, amanhã mesmo a gente vai ficar aqui no Banco do Brasil, isso aí deixa o pessoal da comunidade muito otimista, porque lá no distrito de Santa Isabel ninguém viaja mais do que a comunidade de São José da Serra. E eu deixo eles bem conscientes, por que isso ? Por causa do jongo, é o carro-chefe. E para que tenha o jongo tem que ter o quê ? União. Sem união não pode. 0 jongo não canta sozinho $\mathrm{e}$ nem dança sozinho, precisa de um grupo. Então é isso que a gente está trabalhando muito com as crianças... amanhã nós vamos estar aí com crianças... dançando o jongo, até criança de seis anos, cinco anos... tem criancinha lá que está com dois anos e já sabe... bota lá e a gente já deixa. É um troço que no passado não podia, mas a gente deixa [por]que eu acho que o salvador da comunidade vai ser o jongo. ${ }^{19}$

Em algum mês de 2003 conheci São José da Serra. Hebe Mattos convidou-me para acompanhá-la em uma visita ao Quilombo, onde sua turma de Historia Oral realizaria entrevistas com os descendentes da última geração de escravos daquela localidade. Além de nossa amizade, o convite devia-se ao fato de que eu estava estudando jongos, lundus e batuques - mas no século XIX!!! Hebe Mattos havia concluído em 1998 o relatório exigido pelo INCRA (Instituto Nacional de Colonização e Reforma Agrária) para atestar a legitimidade das demandas da comunidade (que se intitulava agora remanescente das comunidades quilombolas) pelas terras da Fazenda São José e pretendia aprofundar a pesquisa sobre suas relações familiares e presença de memórias do cativeiro. Há algum tempo conversávamos sobre a comunidade e especialmente sobre a presença do jongo ali, uma expressão cultural que já não mais imaginava existir nas antigas terras escravistas do sudeste. Muito menos que, logo depois, em 2005, o jongo, através de uma solicitação exatamente de São José da Serra e do jongo do Morro da Serrinha, de Madureira, subúrbio da cidade do Rio de Janeiro, receberia o título de patrimônio cultural do Brasil, a partir do Decreto 3.551 de 2000, pelo Instituto do Patrimônio Histórico e Artístico Nacional (IPHAN) ${ }^{20}$.Eu era uma pesquisadora das festas do século XIX e fazia exatamente um levantamento de fontes e de bibliografia sobre os jongos. Assídua leitora dos folcloristas do final do século XIX e início do XX, e evidentemente influenciada por eles, havia imaginado que o jongo tinha mesmo desaparecido em algum momento do século XX, como tinham previsto tantos folcloristas. Grande equívoco.Quando assisti pela primeira vez à festa de maio, em 2005, pude confirmar a certeza de que algo estava realmente mudando e o silêncio reservado e imposto ao jongo e aos jongueiros do sudeste, pela bibliografia especializada, fossem folcloristas, antropólogos ou historiadores, estava sendo quebrado. Como constatamos depois, nossa pesquisa teve o privilégio de acompanhar o movimento de emergência de novas comunidades quilombolas, jongueiras e negras no velho sudeste escravista. E um 
dos melhores canais para a quebra desse silêncio - que pode ser também entendido como um movimento de (des)guetificação - foram exatamente as festas de maio em São José, com jongos, seguidos de perto por calangos e folias de reis, como veremos ${ }^{21}$. 0 valor hoje atribuído ao jongo, de patrimônio de um grupo e de uma nação, demonstra, contundentemente, o quanto estamos distantes dos primeiros registros e avaliações letradas sobre este tipo de manifestação cultural. No século XIX, autoridades governamentais e viajantes estrangeiros costumavam denominar os jongos de batuques, atribuindo-lhes marcas racistas, costumeiramente associadas aos africanos: "danças bárbaras", "música selvagem e rude", "maneiras selvagens e grotescas"22. Em 1892, o letrado Coelho Neto (1864 - 1934), numa crônica no Jornal o País, no dia primeiro de janeiro, depois de assistir a uma celebração em uma fazenda de Vassouras pela passagem do ano, definia o jongo como a dança de africanos, "triste na sua brutalidade e na sua monotonia, selvagem e bárbara como a terra da sua origem". Era uma dança do exílio, uma "representação saudosa da pátria longínqua". No momento em que escrevia, Coelho Neto era categórico quanto ao seu fim e sentenciava que agora se ouvia cada vez menos - Caxambu e "só de longe era possível ouvir seu rugir, no fundo de algum vale". Para o autor, já não havia "mais odiosidades" e "a tristeza teve o seu final". "Os gritos guturais" estavam sendo esquecidos, pois os africanos adotaram o nosso Deus e relegaram os instrumentos d'África, preterindo-os pelo trombone e flauta. $\mathrm{Na}$ avaliação do autor, iam "apagando a dolorosa tradição do exilio". A aposta de Coelho Neto no esquecimento da África no Brasil, apesar de ter sido em parte derrotada, acabou fazendo longa carreira em trabalhos de folcloristas e musicólogos que torciam animadamente para o surgimento de uma música mestiça e popular, fruto da interação das três raças formadoras, até período avançado do século $\mathrm{XX}^{23}$.Nos anos 30 e 40 do século $\mathrm{XX}$, se os folcloristas chegaram a reconhecer a persistência do jongo, motivo então do registro, muitas vezes em dias próximos ao 13 de maio, como vimos, reforçaram a certeza de que estava condenado ao enfraquecimento e à invisibilidade, em termos do número de dançarinos, inspiração musical e poética ${ }^{24}$. Jamais alcançaria os dias de hoje como patrimônio de algum grupo, muito menos da nação brasileira. Até mesmo para Stanley Stein, a perda parecia inevitável. Numa nota de pé de página, avaliou que "a tradição do caxambu sobreviveu em Vassouras, embora esteja rapidamente desaparecendo à medida que os antigos escravos se tornam poucos" 25

5 Em nossa avaliação, os prognósticos sobre o desaparecimento do jongo acompanharam de perto - e talvez seja mesmo um sintoma - o desinteresse por pesquisas sobre os descendentes de escravos nos velhos vales do café do sudeste, suas lutas sociais, políticas e culturais depois do 13 de maio, como a historiografia já vem denunciando há algum tempo. Através de tintas mais fortes, podemos dizer que esses prognósticos, assim como a desqualificação da riqueza poética dos versos de jongo e dos jongueiros ${ }^{26}$, relacionam-se diretamente com a exclusão imposta aos libertos no pós-abolição e com o silêncio sobre sua história. Em nosso ver, esquecer determinada história e patrimônio é, de alguma forma, contribuir para a guetificação de grupos e de suas expressões culturais. Como duas faces de uma mesma moeda, o jongo foi escondido e os jongueiros também procuraram se esconder.Para além da quebra do silêncio do jongo e visibilidade que ganharam os jongueiros no século XXI, emblematicamente a partir das festas de São José, é importante propor e pensar que o jongo, de fato, nunca morreu. Escondido e guetificado, permaneceu protegido por famílias de jongueiros no fundo dos quintais dos subúrbios de pequenas e grandes cidades; em sítios e fazendas onde se isolavam e eram isolados ${ }^{27}$. Continuou como um patrimônio familiar passado de pai 
para filho - e não foi esquecido, assim como a data da Abolição da escravidão. Festas de batuque, jongos e caxambus, nas antigas fazendas de café ocuparam um espaço fundamental de luta para escravos e libertos ao longo do século XIX. Era algo pelo qual valia a pena lutar ${ }^{28}$. Ao lado da defesa da família, do acesso à terra e à própria liberdade, as reuniões festivas com batuques estiveram na pauta das reivindicações de escravos e assim continuaram entre seus descendentes. Tornaram-se local fundamental de encontro e fortalecimento das comunidades; tornaram-se patrimônio do grupo, embora tenham sido perseguidas por autoridades e desvalorizadas por diversos folcloristas e letrados que chegaram a encontrá-las.No final do século XX e XXI, novas demandas dos movimentos negros, como as ações afirmativas, o direitos à identidade quilombola e à diversidade, encontraram as festas de São José em processo de importante transformação. Ambos potencializaram suas ações : o patrimônio cultural festivo ganhou novas dimensões políticas e culturais; os movimentos negros encontraram novas formas de luta e afirmação identitária através da valorização de expressões culturais ${ }^{29}$. Para além do jongo, essas transformações podem também ser sentidas em festas do congado, sambas de roda e maracatus em diferentes locais do Brasil.

\section{Uma grande festa}

Era 2005 quando compareci pela primeira vez a uma festa em São José da Serra. Lembro-me bem de uma fantástica e estrelada noite de maio, numa área rural do município de Valença, já quase Minas Gerais. Ao nosso lado, turmas de graduação da Universidade Federal Fluminense (UFF) e centenas de visitantes de fora da região atraídos pela novidade da visita a um quilombo, onde se dizia dançar e cantar versos do tempo dos escravos. Sem dúvida, não era fácil explicar para os alunos e interessados que aquele local da festa, apesar de algumas impressões, era muito diferente do ambiente do século XIX, quando não havia campo livre para o gado ou para a presença de uma comunidade isolada como a de São José. Naquele tempo o café ocupava todo o mar de morros da região; a ferrovia cortava os caminhos e o movimento dos trabalhadores escravos e mercadores era significativo. Hoje, de uma forma impactante, o celular não pegava, a luz havia chegado há pouco e as casas dos quilombolas eram de pau a pique, com chão de terra e quintal cheio de galinhas e flores (16 casas, cerca de 7 dezenas de habitantes em 2003). As pequenas casas espalhavam-se e espremiam-se entre a base da montanha, como uma espécie de moldura, e o largo vale, onde o proprietário oficial das terras gostava de expor as cercas de arame e alguns bois. De longe, era difícil ver as casas de pau a pique, indicando mesmo que a comunidade (re) construíra suas casas após a abolição, em local que também servia de refúgio e esconderijo - escondia-se e era escondida (de novo duas faces da mesma moeda). Numa área comum de terra batida, ao redor de um largo terreiro, acontecia a festa. Bem ao lado erguia-se a igrejinha, um barracão coberto, a cozinha e duas pequenas salas de aula. Lâmpadas acesas penduradas davam o clima de festa do interior. 
'Local central das festas do Quilombo de São José da Serra' Arquivo Labhoi, 2005

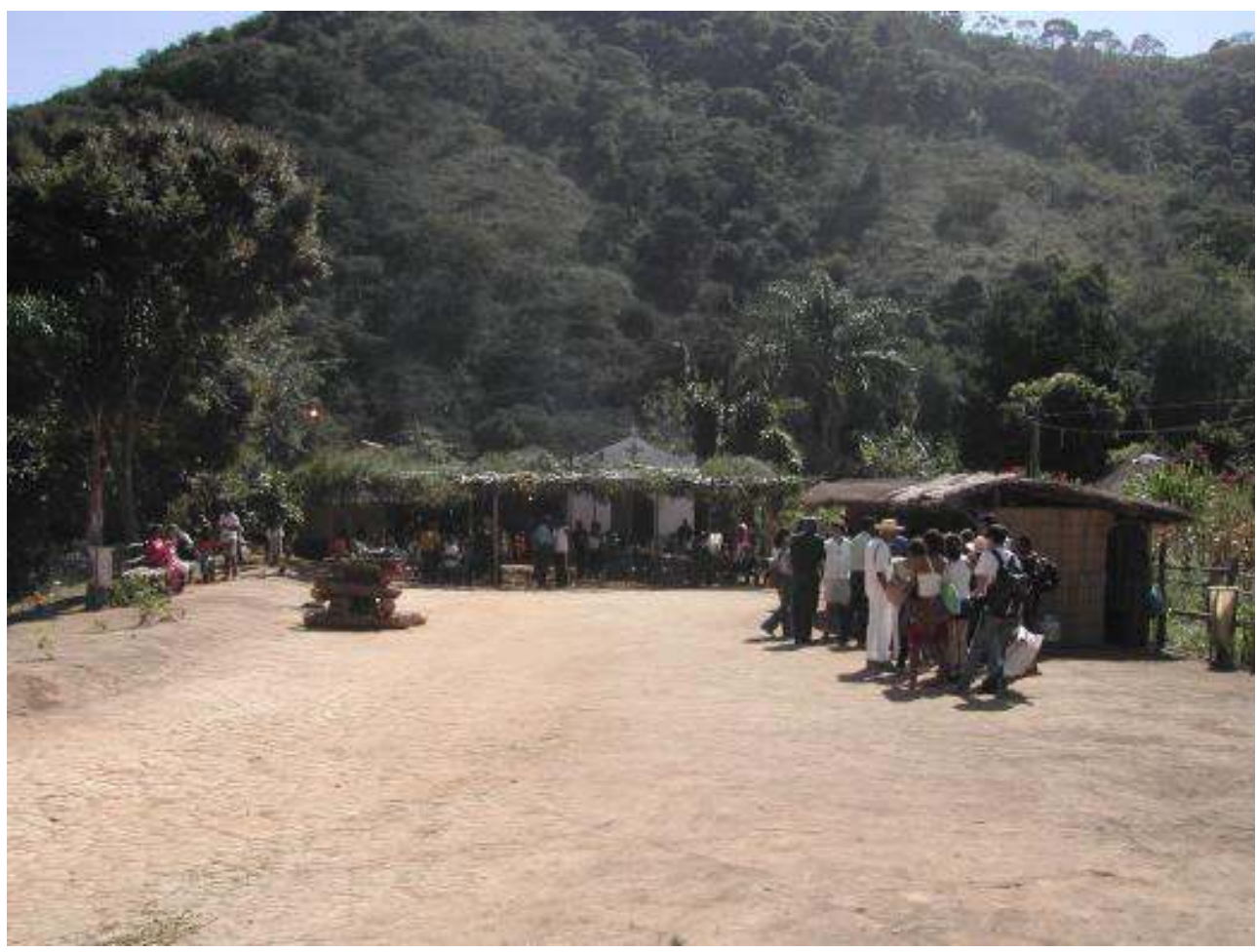

7 Desde o almoço, onde foi saboreada uma deliciosa feijoada, eu e Hebe Mattos ficamos impressionadas com a chegada de vários grupos de jongo e de folias de reis ${ }^{30}$ num lugar muito distante do asfalto e de difícil acesso nos dias atuais. Formados majoritariamente por negros, os grupos pareciam vir de muito longe. Em pouco tempo identificamos grupos de municípios próximos, como Barra do Piraí e Pinheiral, até mesmo de outros rincões de Valença. Outros se deslocavam de locais mais distantes, como Bracuí (Angra dos Reis), Santo Antonio de Pádua e Quissamã, do norte e noroeste ao litoral do estado do Rio. Os calangos, dança de casal e música com sanfona, viola e pandeiro, aconteciam nos intervalos das apresentações dos jongos, ou entre uma ou outra visita das folias de reis, no barracão coberto e movimentadíssimo. Os festeiros demonstravam gostar muito dos bailes de calango. Preciso confessar que, de início, fizemos uma avaliação completamente equivocada dos calangos. Achávamos que era uma pobre e distorcida imitação dos forrós nordestinos e que atrapalhavam o que acreditávamos ser os tradicionais e autênticos jongos. Em breve iríamos descobrir que os calangos também faziam parte do conjunto de expressões musicais e poéticas negras, patrimônio dos descendentes de escravos da região. De uma forma próxima aos jongos e as folias de reis, os calangos e seus versos são praticamente desconhecidos ${ }^{31}$.

8 Ao longo da festa, crescia a minha sensação de surpresa e emoção. Parecia evidente, como confirmamos depois, que todos eram descendentes de escravos e representantes do campesinato negro que emergiu a partir da Abolição, como os festeiros da comunidade de São José da Serra. Traziam consigo - e com muito orgulho - a herança de seus antepassados, as memórias do cativeiro e das lutas do pós-abolição através de versos, desafios, danças, músicas e orações para os santos reis. Cada grupo que chegava com sua folia, jongo ou instrumentos do calango ${ }^{32}$ parecia abrir uma janela de sua própria história, ao representarem um determinado passado, renovado no novo contexto da festa e das lutas políticas dos últimos 20 anos. Como em muitas outras 
festas, ali se encontram o passado, o presente e o futuro. No palco central, a identidade negra e quilombola de São José e seus planos para o futuro. Em meio à surpresa, logo passamos a fazer várias perguntas, impossíveis de serem rapidamente respondidas. Onde estavam ou estiveram esses grupos até agora? Por que historiadores da escravidão e da cultura pouco ou nada sabiam sobre essas festas e expressões ? Por que essas pessoas ficaram invisíveis tanto tempo (ou teriam sido invisibilizadas)? Rapidamente nossas perguntas multiplicaram-se : O que estavam todos fazendo ali ? Como se conheciam? De onde estavam saindo? Por que se encontravam dessa forma? Por que nunca tínhamos ouvido falar desses encontros e da existência do jongo e folia de reis em local tão próximo à cidade do Rio de Janeiro ? E o calango ? Por que não conhecíamos a ação cultural e política dos libertos e suas lutas no período após a Abolição ?Apesar de tantas perguntas, eu e Hebe Mattos conseguimos perceber que para aquelas pessoas não havia muita novidade no que ali estava acontecendo. Todos pareciam conhecer essa forma de comunicação na festa. Expressavam-se e comunicavam-se através de uma linguagem cultural e festiva muito conhecida por todos. Em meio a particularidades, os jongueiros podiam participar e sabiam "entrar" na roda de jongo dos outros grupos; também acompanhavam com facilidade as evoluções e desafios em versos dos grupos de folia de reis que chegavam de tempos em tempos. Bem diferente da platéia, os festeiros conheciam e entendiam as disputas e os desafios dos versos de calango. Pareciam conhecer e compartilhar todas aquelas atrações.Não demoramos a entender que precisávamos organizar um novo projeto de pesquisa a partir das Festas do Quilombo de São José. Além de nossos interesses individuais de pesquisa, apresentamos um projeto à Petrobrás Cultural, em 2005, no Edital Cultura Imaterial : Jongos, calangos e folias, memória e música negra em comunidades rurais do Rio de Janeiro.

9 A base desse projeto, além da festa que assistimos, era a pesquisa já consolidada por Hebe Mattos e Ana Lugão Rios sobre a memória do cativeiro de descendentes da última geração de escravos do Vale do Paraíba, em especial de São José da Serra, e a emergência do campesinato negro após a Abolição. O livro Memórias do Cativeiro havia acabado de ser publicado e finalizávamos nossa primeira escrita videográfica da história a partir do próprio livro e de novas entrevistas em São José da Serra ${ }^{33}$. Com os trabalhos de referência de Ana Lugão Rios e Hebe Mattos, questões específicas sobre o pós-abolição, como o trabalho na roça, a organização familiar, a mobilidade espacial, as lutas e os direitos dos trabalhadores no campo, começavam a ganhar a devida atenção no Brasil como problema historiográfico. Tratava-se de amplificar tal experiência e articular tudo isso com as lutas atuais pela terra, com a emergência da identidade quilombola, com as festas e, finalmente, com os jongos, calangos e folias que tínhamos assistido em São José da Serra. O maior objetivo do projeto foi então o inventário e o registro das expressões musicais negras no estado do Rio de Janeiro, bem como a memória e a história das comunidades protagonistas das expressões culturais em foco. Paralelamente, nos comprometemos com a criação de um centro de pesquisa e referência áudio-visual, a partir das gravações e filmagens produzidas pelo projeto, e com a produção de mais um DVD que contasse a história das comunidades e dos jongos, calangos e folias. Entendíamos que os historiadores da escravidão, das relações raciais e da música negra poderiam contribuir para tanto, fornecendo subsídios para a compreensão da história dessas expressões musicais desde, pelo menos, as últimas décadas da escravidão $O$ projeto também pretendia preencher uma lacuna sobre a produção musical negra no Rio de Janeiro. A história da música no Brasil possuía - e 
ainda possui - poucos estudos historiográficos e suas principais versões ainda são comprometidas com determinadas visões da identidade nacional mestiça brasileira ${ }^{34}$.

\section{Uma pesquisa e um filme : Jongos, Calangos e Folias}

10 Como todo bom projeto, organizamos um levantamento bibliográfico sobre as expressões culturais e sobre as regiões dos entrevistados - hoje disponível on line ${ }^{35}$ que confirmou a inexpressiva produção a respeito dos descendentes de escravos e seu patrimônio cultural no Rio de Janeiro. Suas histórias tinham mesmo sido negligenciadas ou esquecidas. Começamos então a pesquisa propriamente dita a partir dos contatos que fizemos na festa de São José da Serra ou a partir de alunos e ex-alunos do curso de história que tinham vínculos familiares com as áreas em foco (como Luana Oliveira de Barra do Pirai, Liliane Brito de Cabo Frio e Antonio Carlos Gomes da Baixada Fluminense). Os conhecimentos anteriores com Toninho Canecão, líder do Quilombo de São José da Serra, entrevistado por Hebe Mattos para a realização do relatório do INCRA, e com Délcio Bernardo, ex-aluno do curso que costumamos ministrar no PENESB (Programa de Educação sobre o Negro na Sociedade Brasileira/UFF) ${ }^{36}$ e liderança jongueira de Angra dos Reis, foram fundamentais para chegarmos mais perto dos grupos que conhecemos na festa. Pelo local de origem desses grupos, ficou evidente que precisaríamos de muitos recursos com viagens, pois nossa pesquisa teria que ser realizada em uma área muito ampla do atual estado do Rio de Janeiro. A partir do litoral norte e sul do estado (Búzios - Quilombo da Rasa e Campos Novos - e Angra dos Reis Quilombo do Bracuí e Mambucaba), caminhamos em direção aos velhos vales do café - o Vale do Paraíba - nas localidades de Barra do Piraí, Pinheiral, Arrozal, São José da Serra e Duas Barras, e retornamos pela Baixada Fluminense, especialmente no município de Mesquita, já bem perto da cidade do Rio de Janeiro. Ao todo teriam que ser percorridos mais de $4000 \mathrm{~km}$ num prazo de 12 meses, entre o final de 2006 e ao longo de $2007^{37}$. Através da história oral, começamos a registrar a memória e a trajetória dos grupos e de suas atividades festivas e musicais. Para isso, realizamos entrevistas com equipamentos de filmagem e organizamos genealogias, reconstituídas através dos depoimentos orais. Quando possível, levantamos registros de nascimento, óbitos e inventários das antigas fazendas. 0 roteiro de pesquisa envolveu entrevistas com os mais antigos e com os principais jongueiros, foliões de reis ou calangueiros das comunidades visitadas. Tudo começava com as perguntas sobre a família, região de origem e levantamento dos antepassados e parentes. Em seguida sobre jongos, calangos e folias. Como aprenderam? Quando faziam? O que significavam para o grupo? Tentávamos articular historia social com história cultural e política. Genealogias familiares com patrimônio cultural. Realizamos também filmagens das principais festas e manifestações musicais. Uma das tarefas mais difíceis da pesquisa foi delimitar as áreas em foco, pois cada grupo que entrávamos em contato, outro era indicado. Sempre alguém conhecia outro jongueiro, calangueiro ou folião em região bem próxima. Evidentemente não conseguimos cobrir todas as indicações e referencias que recebemos. Não alcançamos o norte e noroeste do estado ; nem a própria cidade do Rio de Janeiro, onde na Serrinha, em Madureira, o grupo de jongo de Tia Maria, com raízes familiares em Valença, município do Quilombo de São José da Serra, realiza ainda hoje importante trabalho cultural e social com o jongo ${ }^{38}$. Em diversos morros cariocas sabemos da chegada de migrantes do Vale do Paraíba, nas primeiras décadas do século $\mathrm{XX}$, que, com seus jongos, calangos e folias, ajudaram a fundar as principais 
escolas de samba da cidade. A equipe precisou ser grande: alunos de iniciação cientifica, alguns da área de cinema e comunicação ; especialistas em filmagens, edição e produção de viagens e filmes. Na volta de cada visita às comunidades, fazíamos reuniões para ouvir os relatos e alguns depoimentos selecionados. Cada fita gravada tinha seu conteúdo decupado em função de nossos interesses de pesquisa: local da gravação, nome do entrevistado, expressões culturais em foco, memória do cativeiro, experiências de trabalho no campo, migrações familiares, genealogias etc... Todo esse material encontra-se hoje disponível on line em nosso "acervo"39.

11 Em cada reunião, as discussões eram intensas e rapidamente nossas suspeitas - ou hipóteses - ganharam corpo. Todos os depoimentos, registrados em diferentes e distantes locais - do sul ao norte do estado do RJ, interior ao litoral - evidenciavam a relação do grupo com a memória da escravidão e com as lutas do pós-abolição. Em todos os depoimentos, muita emoção em histórias de vida que vinha à tona através de lembranças familiares, saudades de amigos, tempos da infância, festas, momentos de alegria e sofrimento.Aos poucos, coletivamente, ao discutirmos todas as entrevistas, comparando-as no tempo e no espaço, o roteiro do filme foi ganhando contornos teóricos e geográficos. Em 2007 estávamos prontos para fechar o roteiro básico de escrita da História em vídeo. Selecionamos, a partir de quase 200 horas de entrevistas, as que não poderiam ficar de fora e realizamos algumas filmagens finais. De uma forma próxima ao que fazemos para construir um artigo ou um livro, passamos a escolher os trechos das entrevistas que seriam citados de uma forma mais longa. No caso do filme, a qualidade da imagem e do som pesava no argumento e na seleção das imagens. A editora do filme, Isabel Castro, também passou a ter um papel fundamental de coautora do próprio filme-texto. Claro, Isabel realizava os cortes da longa pesquisa com imagens e depoimentos áudio-visuais. Ainda em 2007, fizemos um pré-lançamento com a presença das principais lideranças das comunidades, com o objetivo de termos a aprovação do material. No final do ano lançamos, no teatro da Universidade Federal Fluminense (UFF), nosso segundo DVD ${ }^{40}$.

12 O roteiro do filme foi em grande parte inspirado no próprio trajeto da pesquisa e em diálogo com o movimento dos africanos aqui chegados e dos seus descendentes. A primeira parte do filme, então, refere-se ao litoral do estado, sul e norte, ponto de desembarque dos últimos africanos chegados como escravos no Brasil, e apresenta as comunidades quilombolas do Bracuí, em Angra dos Reis, e Rasa, em Búzios. A segunda parte sobe a Serra do Mar, chega ao Vale do Paraíba, o velho vale do café no século XIX, para onde se dirigiu a maioria dos recém chegados. Ali são entrevistados representantes das comunidades de Barra do Piraí, Quilombo São José da Serra e Duas Barras. A terceira e última parte, desce a serra, e atinge a Baixada Fluminense, especialmente Nova Iguaçu, Mesquita, Duque de Caxias e São João do Meriti, para onde muitos ex-escravos e seus descendentes se dirigiram, no pós-abolição, em diferentes momentos do século XX, na busca por melhores oportunidades de trabalho. Para o argumento central do filme, a pergunta formulada na festa de São José voltava a ganhar papel central: o que todos os grupos tinham em comum? O filme registra como diferentes regiões do estado do Rio de Janeiro estão marcadas pela presença expressiva da população negra, descendente a última geração de escravizados e identificada, na prática ou na memória, com jongos, calangos e folias. Em distantes regiões, narrativas coincidentes. Em diferentes locais, versos, desafios e improvisos estruturam a forma de cantar, contar histórias e festejar. Recorrentes são as histórias e memórias sobre 
antepassados escravos e africanos (muitos desembarcados ilegalmente após 1831 e 1850). Recorrentes são os sentimentos sobre a luta pela terra, sobre o duro trabalho camponês, sobre pais, mães e avós jongueiras, calangueiras e foliões, sobre a alegria dos encontros para essas expressões e sobre o respeito aos mais velhos (sempre chamados de "grandes jongueiros" e "grandes calangueiros"). Coincidentes são as trajetórias dos que ficaram próximos aos locais de trabalho de seus pais e avós ou dos que realizaram migrações para novas áreas de trabalho, algumas até mais distantes como a Baixada Fluminense e os morros cariocas.Marcantes também são as histórias de discriminação racial e de exclusão, ao lado do fortalecimento da identidade negra. No filme, essas histórias são reveladas através de desafios verbais entre "pretos e brancos" e de versos que expressam o orgulho de ser negro ou afirmam que a liberdade não foi de nosso jeito. A melhor de todas as histórias, contadas em variadas versões por diferentes grupos, valoriza a presença do "rei negro" - às vezes chamado de Belchior, outras de Baltazar frente aos outros dois famosos reis magos brancos. Em torno da visita a Jesus recémnascido, data comemorada no dia 6 de janeiro, o Rei Negro teria chegado primeiro, apesar dos esforços dos outros reis que usam estratégias não muito corretas para conseguirem chegar antes. Em relação à memória do cativeiro também está presente no filme uma impressionante tradição oral envolvendo histórias de antigos senhores, seus castigos, riquezas, doações de terras a ex-escravos e ações no tráfico ilegal, como as histórias do Quilombo do Bracui são exemplares ${ }^{41}$. Sem dúvida, se toda essa história pode ser contada hoje é somente porque continuou presente na performance das festas e no impressionante repertório das danças, músicas e versos de jongos, calangos e folias. O título do filme, Jongos, Calangos e Folias - Música Negra, Memória e Poesia - revela exatamente esse complexo cultural construído coletivamente ao longo dos séculos XIX, XX e XXI. Jongos, Calangos e Folias apresentam evidentes marcas africanas (como os tambores, as batidas e os versos de desafio e improviso centro-africanos presentes nas três expressões). Mas não só. São visíveis, e muito fortes, até mesmo nos jongos, as marcas crioulas (como as sanfonas dos calangos e folias e os improvisos em língua portuguesa dos jongos) e as matrizes católicas (com a presença dos santos reis e de versos e festas para São Pedro, São Benedito e Nossa Senhora do Rosário). Jongos, calangos e folias possuem muitos trânsitos e aproximações culturais e musicais. Afinal, foram criados e construídos pelos mesmos atores sociais. Nesse sentido, revelam um complexo cultural, uma gramática e um repertório comuns, expresso principalmente numa belíssima estrutura poética de versos, desafios e improvisos ${ }^{42}$. Trânsitos culturais evidentes contrastam com a emergência de uma poderosa identidade negra ${ }^{43}$. Descobríamos muito mais do que tínhamos imaginado. Voltando a São José, podemos concluir que suas festas podem ser entendidas como a expressão mais visível desse universo cultural, social e geográfico muito mais amplo. Independente de nossas perguntas, a festa permitia que os descendentes da última geração de escravizados dos vales do café falassem do passado e do presente, através de versos e desafios, de seu próprio mundo. Mais ainda, a festa permitia que os jongueiros, calangueiros e foliões de reis se tornassem visíveis, mesmo que isolados em seus municípios, mesmo que em meio a dificílimas condições de vida e trabalho, mesmo que ainda longe de terem a certeza da titulação de suas terras e ou da valorização de seu patrimônio cultural. Chegar aos dias de hoje com jongos, calangos e folias era também uma forma de afirmar seus direitos de organização, encontro e diversão em função de seus próprios santos e valores, danças e músicas. A festa tornava-se um efetivo exercício de seu patrimônio. 
'A roda de jongo da comunidade de São José da Serra. Sr. Manoel Seabra ao centro.'Arquivo Labhoi, Festa de 2005

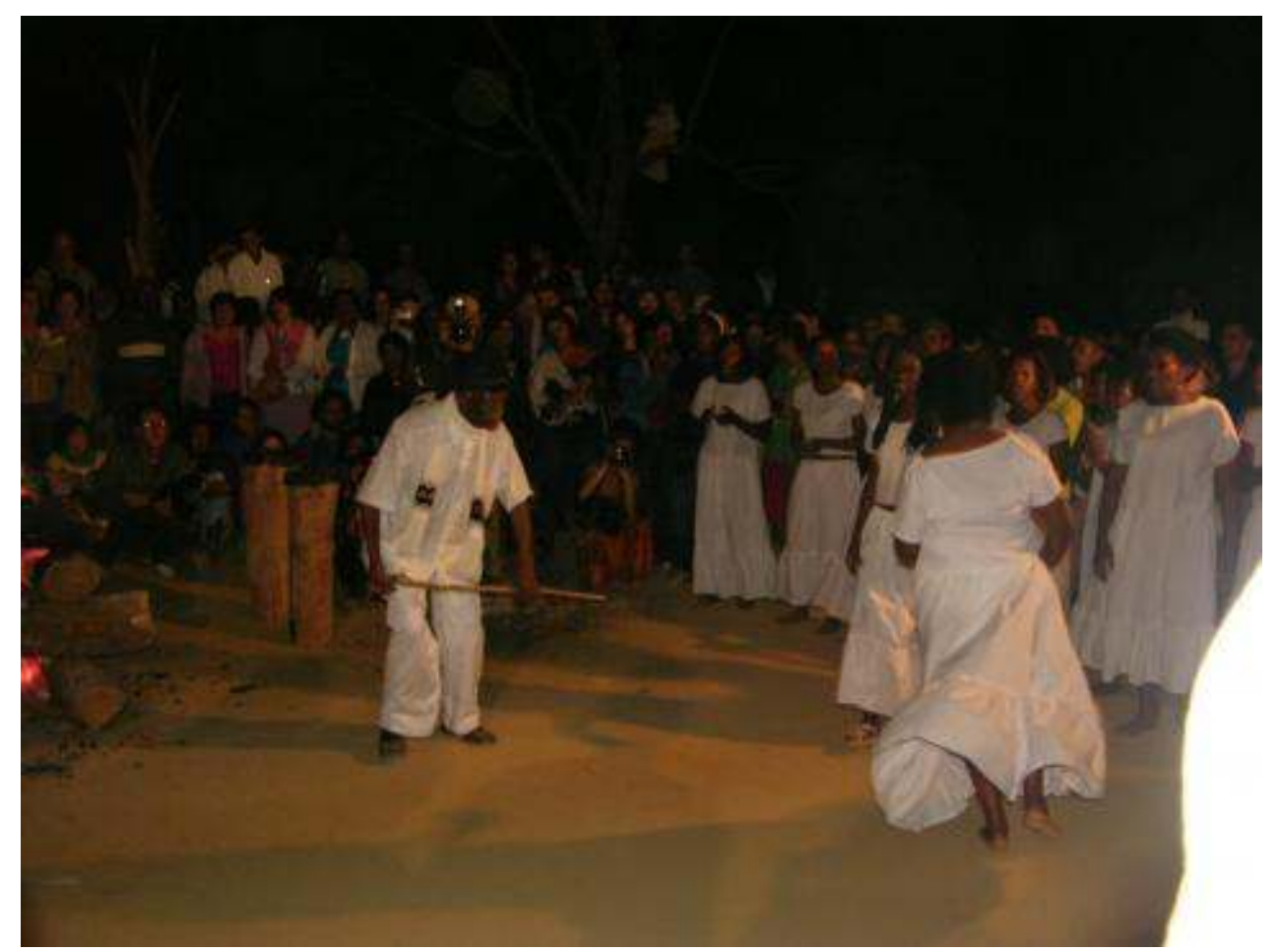

\section{Ainda uma nota sobre os jongos e os jongueiros}

Sem dúvida, entre jongos, calangos e folias, os jongueiros conseguiram atribuir um valor simbólico e político mais significativo a essa prática. Mesmo que transitem entre calangos e folias de reis, ou que tenham sido grandes calangueiros e palhaços de folias (como o Sr. Manoel Seabra de São José da Serra é o melhor exemplo) os jongueiros, e consequentemente o jongo, ganharam hoje maior visibilidade, especialmente depois do título recebido em 2005, pelo IPHAN (Instituto do Patrimônio Histórico e Artístico Nacional), de Patrimônio Cultural do Brasil.Mas mesmo antes do recebimento do título, já era visível o aumento da presença do público e de muitos especialistas nas festas de São José da Serra. Antropólogos, músicos, cineastas, produtores culturais e até mesmo historiadoras, como as autoras desse texto, ficavam mais fascinados pelo jongo, entendido como expressão das raízes africanas da música negra e do samba. Calangos, prováveis imitações dos forros, e folias, ícones da tradicional dominação católica, não exerciam grande atração para os que vinham de fora, como já fiz referência. A mobilização para a visita a São José girava mesmo em torno do jongo. $\mathrm{E}$ a comunidade rapidamente entendeu isso, apesar de nunca ter cancelado ou desprezado as apresentações de calango e folias de reis em suas festas.Vale sublinhar, contudo, que não foram os especialistas os responsáveis pelo início da mobilização em torno do jongo. Os próprios jongueiros começaram toda essa história e escolheram o jongo - e não os calangos ou folias de reis - como canal de encontro e mobilização política. E essa não parece ter sido a primeira vez, pelos registros anotados por Jaime de Almeida, entre os anos de 1916 e 1917, como evidenciamos no início desse texto... Os primeiros encontros de jongueiros começaram em meados da década de 1990, antes do decreto de 2000 sobre os direitos dos detentores do Patrimônio Imaterial e do título de 2005. Em 
2000 foi organizada a Rede de Memória do Jongo, que rapidamente começou a reunir um razoável número de comunidades jongueiras. Nessa mesma década, São José da Serra iniciou sua demanda pela terra e afirmação de uma identidade quilombola. Só depois desses movimentos dos jongueiros é que surgiram os especialistas, os historiadores e muitos outros técnicos e profissionais da educação e da cultura com as novas políticas públicas, como o Programa Nacional do Patrimônio Imaterial (2000) e as Diretrizes Curriculares para a Educação das Relações Étnico-Raciais e para o Ensino de História e cultura afro-brasileira e africana (2004). Precisamos confessar que nossos projetos com as comunidades jongueiras seguiram em frente não apenas em função de nosso interesse acadêmico específico em escravidão/pós-abolição e/ou cultura e música negra. Obviamente, sabemos que nossa presença ou produção acadêmica estimula memórias, reforça recordações e incentiva narrativas. Mas são as próprias comunidades jongueiras que levam essas histórias adiante com apoio de outros especialistas e acesso direto a financiamentos. De fato, as comunidades jongueiras procuram recontar e tornar visível suas histórias e patrimônio, a despeito de nossa presença ou interesse. Certamente não temos o monopólio de suas histórias, muito menos somos seus únicos interlocutores. Entretanto, já fomos muito longe... Não é mais possível desistir de acompanhar todo esse movimento dos descendentes de escravos do velho Vale do Paraíba. Nossos projetos seguiram em frente com a produção de entrevistas com jovens lideranças e com a produção de novos filmes, lançados em 2009 e 2011 - Versos e Cacetes, o Jogo do Pau na cultura afro-fluminense, e Passados Presentes, memória negra no sul fluminense. ${ }^{44}$ Desde a festa que assistimos em 2005, sem dúvida, muita coisa aconteceu. Grupos de jongueiros, ao emergirem em diversos locais de São Paulo, Rio de Janeiro, Minas Gerais e Espírito Santo, mostraram para os próprios jongueiros a extensão do jongo no sudeste - suas aproximações e diversidades. Articularam-se no Pontão de Cultura do Jongo e Caxambu, uma rede de comunidades jongueiras associadas ao IPHAN, Museu do Folclore e UFF (Universidade Federal Fluminense) ${ }^{45}$, e, a partir daí, produziram material didático, sites, outros filmes, pequenos centros de memória, seminários e muitos encontros, que viabilizam a sua existência e a produção de uma narrativa autônoma. Desde então, o movimento ampliou-se ao lado do fortalecimento das ações afirmativas. Alguns grupos ainda associaram a luta pela valorização do jongo à construção de uma nova identidade quilombola que reivindica acesso à terra e à construção de locais de memória para o jongo e para sua história. Por outro lado, é verdade, pouca coisa mudou em relação às duras condições de vida das comunidades jongueiras. São José da Serra ainda não recebeu a titulação definitiva; no Bracui, a herança recebida dos Souza Breves em testamento ainda não está em suas mãos. Muitos grupos não conseguem estabelecer centros de referência para visitação, nem apoio das prefeituras ou secretarias de cultura apesar de terem recebido o título de Patrimônio Cultural do Brasil. Até mesmo os jovens das comunidades encontram dificuldades para completar o Ensino Médio. Poucos chegam à universidade. Mesmo assim, é possível também perceber mudanças. Os jongueiros não têm mais medo ou vergonha das perseguições e preconceitos. Em cada festa que temos a oportunidade de participar, percebemos o envolvimento dos jovens e o orgulho de uma história que começa a ter mais visibilidade. A tradição parece fazer sentido e atualiza-se em função de uma luta contra o racismo e acesso completo aos diretos de todos os cidadãos. 0 jongo deixou de ser coisa de velho ou de um passado que não se quer lembrar. Pelo contrário, muitos grupos reaprendem o jongo, criam escolas para crianças e (re) lembram que ele existia em suas famílias, desde muito tempo. 


\section{BIBLIOGRAFIA}

ABREU, Martha. Cultura Imaterial e Patrimônio Histórico Nacional. In : Abreu, M., Soihet, R. e Gontijo, R. Cultura Política e Leituras do Passado. Rio de Janeiro, Civilização Brasileira, 2007.

ABREU, Martha e DANTAS, Carolina Viana. "Música Popular e História” in Lopes, H., Abreu, M., Ulhoa, M.T., Velloso, M.P. Música e História no longo século XIX. Rio de Janeiro, Fundação Casa de Rui Barbosa, 2011.

ABREU, Martha e VIANA, Larissa. Festas religiosas, cultura e política no Império do Brasil. In : Grimberg, Keila e Salles, Ricardo. O Brasil Império. Vol III, 1870-1889. Rio de Janeiro, Civilização Brasileira, 2009 ;

ABREU, M., SOIHET, R. e GONTIJO, R. Cultura Politica e Leituras do Passado. Rio de Janeiro, Civilização Brasileira, 2007.

AGOSTINI, Camila. Africanos no cativeiro e a construção de identidades no Além-Mar, Vale do Paraíba, século XIX. Dissertação de Mestrado, Campinas, Unicamp, 2002.

ALMEIDA, Jaime. Foliões e festas em São Luís do Paraitinga na passagem do século, 1888-1918. Tese de doutorado. São Paulo, Universidade de São Paulo, 1988.

ARAUJO, Alceu Maynard. Folclore Nacional Volume II. São Paulo, Melhoramentos, 1964.

BITTER, Daniel. A Bandeira e a Máscara. A circulação de objetos rituais nas folias de reis. Rio de Janeiro, 7 Letras, IPHAN/CNFCP, 2010.

CUNHA, Clementina P. Carnavais e Outras $F^{\circledR}$ estas. Campinas, Ed. Unicamp : Cecult, 2002.

DOMINGUES, Petrônio. Movimento negro Brasileiro : alguns apontamentos históricos. Revista Tempo, n. 23, vol. 12, Niterói, julho 2007.

Salve o 13 de maio : as comemorações da abolição da escravatura. In : Anais do XXVI Simpósio Nacional de História - ANPUH, São Paulo, julho 2011.

GALLET, Luciano. Estudos de folclore. Rio de Janeiro, Carlos Wehrs e Cia.,1934.

JANCSÓ, István e Íris KANTOR (orgs.) Festa. Cultura e Sociabilidade na América Portuguesa. São Paulo, Imprensa Oficial, Hucitec, Edusp, Fapesp, 2001.

LARA, S. e PACHECO, G. Memória do Jongo. As Gravações Históricas de Stanley Stein. Vassouras, 1940. Rio de Janeiro, Folha Seca, Campinas : Cecult, 2007

LODY, Raul “Jongo, alegria do corpo e lenitivo da alma”. Revista Fluminense de Folclore 3, n. 6, ago. 1976.

MATTOS, Hebe e ABREU, Martha. Jongo, Registros de uma História. In : Lara, S. e Pacheco, G. Memória do Jongo. As Gravações Históricas de Stanley Stein. Vassouras, 1940. Rio de Janeiro, Folha Seca, Campinas : Cecult, 2007.

MATTOS, Hebe e ABREU, Martha. Quilombos contemporains. Mémoire de l'esclavage, culture afrobrésilienne et citoyenneté au Brésil. In : Saillant, F. Et Boudreault-Fournier, A. (org) Afrodescendances, Cultures et Citoyenneté. PUL - Presses de L'Uniiversité Laval, 2012.

MORAES, Renata. As Festas da Abolição : 013 de Maio e seus significados no Rio de Janeiro (1888-1908). Tese de Doutorado. PPG em História Social da Cultura, PUC. Rio de Janeiro, 2012. 
NEPOMUCENO, Eric Brasil. Carnavais da Abolição : Diabos e Cucumbis no Rio de Jeneiro 1879-1888. Dissertação de Mestrado. PPG em História Social, UFF, Niterói, 2011.

OLIVEIRA, Luana. Jongo no Sudeste : Patrimônio Imaterial e Políticas Públicas. In : VI ENECULT, FacomUFBa, Salvador, 2010.

PEREIRA, Camila Mendonça. Abolição e Catolicismo. A participação da Igreja Católica na extinção da escravidão no Brasil. Dissertação de Mestrado. PPG em História Social, UFF, Niterói, 2011.

PEREIRA, Matheus Serva. Uma viagem possível. Da escravidão à cidadania. Quintino de Lacerda e as possibilidades de integração dos ex-escravos no Brasil. Dissertação de Mestrado. PPG em História Social, UFF, Niterói, 2011.

PRICE, Richard. O Milagre da Crioulização : retrospectiva. In : Estudos Afro-Asiáticos. vol. 25, no. 3, Rio de Janeiro, 2003.

RAYMOND, Lavínia Costa, Algumas Danças Populares no Estado de São Paulo, Boletim n.101, Sociologia, n.6, USP, Faculdade de Filosofia, Ciências e Letras, São Paulo, 1954.

RIBEIRO, Maria de Lourdes Borges Ribeiro. O jongo. Rio de Janeiro, Ministério da Educação, Secretaria da Cultura, Funarte, 1984.

RIOS, Ana Lugão e MATTOS, Hebe. Memórias do cativeiro. Família, trabalho e cidadania no pós-abolição. Rio de Janeiro : Civilização Brasileira, 2004.

STEIN, Stanley. Vassouras. Um Município Brasileiro do Café, 1850-1900. Rio de Janeiro : Nova Fronteira, 1990.

SLENES, Robert. "Eu Venho de Muito Longe, eu Venho Cavando" : jongueiros cumba na senzala centro africana. In : Lara, S. e Pacheco, G. Memória do Jongo. As Gravações Históricas de Stanley Stein. Vassouras, 1940. Rio de Janeiro : Folha Seca, Campinas : Cecult, 2007.

SOARES, Antonio J. de Macedo Soares. Dicionário bibliográfico de língua portuguesa. Rio de Janeiro, Instituto Nacional do Livro, 1954 [1889], vol. 1.

SOUZA, Silvia Cristina Martins de Souza. Carpinteiros Teatrais, Cenas Cômicas e Diversidade Cultural no Rio de Janeiro. Ed. UEL, 2009.

\section{NOTAS}

1. Ver JANCSÓ e KANTOR, 2001 : p. 5-16.

2. Ver CUNHA, 2002 : p. 11-24

3. A comunidade de São José da Serra é formada por descendentes de uma família de escravos. Mantiveram-se na terra após Abolição da escravidão e procuraram garantir, ao longo do século XX, o acesso à terra, à economia camponesa e aos laços familiares. Para Hebe Mattos e Ana Rios, "acionaram uma memória do cativeiro para legitimar a posse de suas terras, antes mesmo da aprovação do dispositivo constitucional", ao mesmo tempo que deram "visibilidade e outros sentidos a antigas práticas culturais de origem africana”. Mattos e Rios, 2005 : p. 299.

4. SLENES, 2007 : p. 127-128.

5. MATTOS e RIOS, 2005 : p. 260.

6. MORAES, 2012, e PEREIRA, 2011. Sobre as comemorações próximas ao 13 de maio de 1888, ver ainda os trabalhos de mestrado de Eric Brasil Nepomuceno e Camila Mendonça Pereira.

7. DOMINGOS, $2011:$ p. 6

8. 013 de maio para as organizações militantes negras transformou-se em Dia Nacional de Denúncia Contra o Racismo. Ver DOMINGOS, 2007. 
9. Revista Ilustrada, n.499, ano 13, 2 de junho de 1888, p. 4.

10. STEIN, 1990 : p. 302 e 303.

11. SOARES, Macedo. 1954 [1889] : p. 256. Maria de Lourdes Borges Ribeiro também faz referência a uma nota no Diário do Comércio do Rio de Janeiro, de 14 de maio de 1889, sobre alegres jongos em São Paulo em comemoração pelo aniversário da lei da abolição. RIBEIRO, 1984 : p. 61

12. ALMEIDA, 1988 : parte I e III.

13. GALLET, 1934 : p. 76.

14. Ver MATTOS E ABREU, 2007 : p. 73-93

15. STEIN, 1990 : p. 303.

16. STEIN, $1990:$ p. 305. Outros pontos permanecerão para sempre nas gravações realizadas pelo autor, no final dos anos de 1940. Essas gravações podem ser localizadas um um CD que faz parte do livro organizado por Silvia Lara e Gustavo Pacheco em homenagem ao autor. LARA e PACHECO :2007.

17. Sobre as relações entre cultura e política e o próprio conceito de cultura política, ver ABREU, SOIHET E GONTIJO : 2007. Sobre as relações entre festa e ação política no século XIX, ver ABREU e VIANA, $2009: 233-270$

18. RIOS E MATTOS, 2005 : p. 300.

19. MATTOS E ABREU, 2007 : pp. 104 e 105.

20. ABREU, $2007: 357$

21. RIOS E MATTOS, 2005. pp. 288-289.

22. MATTOS E ABREU, 2007, pp. 175-178.

23. O próprio Coelho Neto estabeleceu um outro local para o jongo : no teatro de revista. Ver SOUZA, 2009.

24. RAYMOND, 1954 : p. 20.

25. STEIN, 1990 : p. 244.

26. Essa desqualificação sobre os versos pode ser encontrada em trabalhos de diversos folcloristas, como Luciano Gallet, Mário de Andrade e Renato Almeida. Claro que podemos citar folcloristas que chegaram a perceber força dos versos e registraram com sensibilidade as festas de jongo, como Lavinia Raymond e Maria de Lourdes Borges Ribeiro.

27. OLIVEIRA, 2010.

28. AGOSTINI, 2002.

29. Ver MATTOS E ABREU, 2012.

30. Grupos que percorrem diversas regiões do sudeste por devoção aos santos reis, especialmente o rei negro, entre os meses de dezembro e janeiro. Mas também fazem apresentações em outras épocas do ano. Ver BITTER, 2010.

31. Sobre as relações entre o Calango e o Samba de Partido Alto, ver o Dossiê das Matrizes do Samba Carioca, p.49-51. Coordenação de Nilcemar Nogueira. www.cnfcp.gov.br/pdf/Patrimonio.../ Dossie.../Dossie_Samba_RJ.pdf

32. Para maiores informações sobre jongos, calangos e folias de reis, ver www.historia.uff.br/ jongos

33. O filme "Memórias do Cativeiro" pode ser visto em http://ufftube.uff.br/video/ M2GWDYGDBYU7/Mem\%C3\%B3rias-do-Cativeiro

34. O filme também foi pensado para atender a finalidades didáticas, no âmbito das Diretrizes Curriculares Nacionais para a Educação das Relações Étnico-Racias e para o Ensino de História e Cultura Afro-brasileira e Africana, aprovadas em 2003.

35. Ver www.historia.uff.br/jongos/acervo

36. O PENESB (Programa de Educação sobre o Negro na Sociedade Brasileira) é um espaço de educação continuada para profissionais docentes sob a temática "Educação para as Relações Étnicorraciais", desenvolvido pela Faculdade de Educação da Universidade Federal Fluminense. 
37. Ver mapa das regiões visitadas presente no site de Jongos, Calangos e Folias. http:// www.historia.uff.br/jongos/?p=6

38. Ver http://www.jongodaserrinha.org.br/v2/index.htm

39. http://www.historia.uff.br/jongos/acervo/

40. O filme "Jongos, Calangos e Folias" pode se visto em http://ufftube.uff.br/video/ 9RBAH0806474/Jongos-Calangos-e-Folias-M\%C3\%BAsica-Negra-Mem\%C3\%B3ria-e-Poesia

41. Sobre essas histórias, produzimos nosso quarto e último filme - "Passados Presentes Memória Negra no Sul Fluminense". Direção Hebe Mattos e Martha Abreu. 2011. http:// www.labhoi.uff.br/passadospresentes/filmes_passados.php

42. Também faz parte desse complexo cultural o "jogo do pau", um jogo de combate, envolvido diretamente com os desafios e bailes de calangos. 0 "jogo do pau" articula a herança africana, as experiências do cativeiro e as redes de sociabilidade no pós-abolição. $O$ conhecimento do "jogo do pau" abre novas pistas para a história da capoeira no sudeste. "Versos e Cacetes. O jogo do pau na cultura afro-fluminense", 2009, é o terceiro filme produzido pelo Labhoi, com a direção e roteiro de Matthias R. Assunção e Hebe Mattos. http://ufftube.uff.br/video/G2SY2DSB1KSS/Versos-eCacetes-O-jogo-do-pau-na-cultura-afro-fluminense

43. Há um fértil debate historiográfico no campo cultural em torno das possíveis continuidades africanas (africanismos) ou inovações culturais denominadas de "crioulização". Ver PRICE, 2003.

44. Lançamos em 2012 uma caixa com os 4 DVDs ("Memória do Cativeiro", "Jongos, Calangos e Folias", "Versos e Cacetes", "Passados Presentes" : http://www.labhoi.uff.br/passadospresentes/ filmes_passados.php

45. Ver www.pontaojongo.uff.br

\section{RESUMOS}

Esse texto tem como objetivo discutir as relações entre festa e luta política, através das comemorações do Treze de maio no Quilombo São José da Serra, situado no município de Valença, estado do Rio de Janeiro. Essas comemorações são estudadas em articulação com a nova política de valorização do patrimônio imaterial e com a emergência do jongo e das identidades negra e quilombola no sudeste do Brasil, entre 1990 e 2010. A pesquisa envolveu a realização de entrevistas, filmagens de jongos, calangos e folias, e a consulta de textos de folcloristas produzidos ao longo do século XX. Dentre os produtos dessa pesquisa, destaca-se o site www.historia.uff.br/jongos e uma caixa de DVDs - Passados Presentes - com 4 vídeos historiográficos (www.labhoi.uff.br/passadospresentes).

Cet article vise à discuter les relations entre fête et lutte politique, à travers les festivités du treize mai dans le Quilombo São José da Serra, à Valença, ville située dans l'Etat de Rio de Janeiro. Ces festivités sont étudiées en relation avec la nouvelle politique de valorisation du patrimoine immatériel et l'émergence du Jongo et de l'identité noire et quilombola dans le sud-est du Brésil, entre 1990 et 2010. La recherche a comporté des entrevues, l'enregistrement de jongos, calangos et folias en vidéo, et la consultation des textes produits par des folkloristes à travers le XXe siècle. Parmi les résultats de cette recherche, on peut indiquer le site www.historia.uff.br/ jongos et une boîte DVD intitulée 'Passés Présents', qui comporte quatre films historiographiques (www.labhoi.uff.br/passadospresentes). 
ÍNDICE

Mots-clés: fête, patrimoine culturel, lutte politique, l'identité noire, quilombo, après l'abolition, jongos

Palavras-chave: festa, patrimônio cultural, luta política, identidade negra, quilombo, pósabolição, jongos

\section{AUTORES}

\section{MARTHA ABREU}

Professora Associada do Departamento de História da Universidade Federal Fluminense. Professora Titular do Departamento de História da UFF.

HEBE MATTOS

Professora Associada do Departamento de História da Universidade Federal Fluminense. Professora Titular do Departamento de História da UFF. 